\title{
Does Bacillus Calmette-Guérin vaccine prevent herpes simplex virus recurrences? A systematic review
}

Laure F. Pittet, MD-PhD ${ }^{1,2}$, Nigel Curtis, MD, PhD. ${ }^{1,2,3}$

1. Infectious Diseases Unit, Royal Children’s Hospital Melbourne, Parkville, Victoria, Australia.

2. Infectious Diseases Group, Murdoch Children’s Research Institute, Parkville, Victoria, Australia.

3. Department of Pediatrics, The University of Melbourne, Parkville, Victoria, Australia.

Running title: BCG vs recurrent HSV

Word count: 2445 words; 2 tables, 2 figures.

Keywords: herpes simplex virus (HSV); cold sore; herpes genitalis; Bacille Calmette-Guérin, Mycobacterium bovis; prevention, secondary prophylaxis.

Corresponding author: Prof Nigel Curtis, Department of Pediatrics, The University of Melbourne, Royal Children’s Hospital Melbourne, 50 Flemington Rd, Parkville, VIC 3052, Australia; nigel.curtis@rch.org.au.

\section{Conflict of interest: none.}

Funding: Dr Laure Pittet is supported by the Swiss National Science Foundation (Early Postdoc.Mobility grant number P2GEP3_178155).

This is the author manuscript accepted for publication and has undergone full peer review but has not been through the copyediting, typesetting, pagination and proofreading process, which may lead to differences between this version and the Version of Record. Please cite this article as doi: $10.1002 /$ rmv.2151

This article is protected by copyright. All rights reserved. 


\section{SUMMARY}

Recurrent infections with herpes simplex virus (HSV) in the orofacial (cold sores), ocular or genital region are common and sometimes disabling, calling for an effective preventive intervention. The bacillus Calmette-Guérin (BCG) vaccine has beneficial off-target effects that might impact recurrence of HSV infections. In this systematic review, Medline, EMBASE and PubMed were searched in June 2020; sixteen articles were deemed relevant comprising eight animal and eight human studies (301 patients). In animals, BCG administration led to a 1.9 to 5.5-fold increase in survival rate following HSV challenge (vaginal, corneal, or intraperitoneal inoculations). This beneficial effect was influenced by the dose of BCG (higher better), mode of administration (intradermal better than intraperitoneal), and the interval between vaccination and viral challenge (minimum of 6 days required). In non-randomised human studies that failed to control for a placebo effect, BCG vaccination appeared beneficial in $78 \%$ of adults with recurrent herpes genitalis or labialis, with $37 \%$ being recurrence-free for an extended period, $41 \%$ experiencing less frequent or severe episodes, and only 22\% reporting no change. This clinical benefit is consistent with the findings of immunological sub-studies. In the two studies restricted to recurrent herpes labialis, 94\% appeared to benefit from BCG. The one randomised controlled trial used an intervention in the control group that has immunomodulatory effects thus limiting interpretation. In conclusion, BCG vaccine is a potential, safe, affordable and readily available candidate to decrease the high burden of disease associated with HSV infection and recurrences, but properly controlled randomised trials are required.

\section{ABBREVIATIONS}

- BCG: bacillus Calmette-Guérin

- HSV: herpes simplex virus

- IQR: interquartile range

- RHG: recurrent herpes genitalis

- RHL: recurrent herpes labialis 


\section{INTRODUCTION}

The herpes simplex virus (HSV), typically associated with orofacial ('cold sore') and genital lesions, is among the most serious human pathogens. ${ }^{1} \mathrm{HSV}$ encephalitis for example, is a severe infection of the central nervous system with a poor prognosis even with antiviral treatment. ${ }^{2}$ After primary infection, the virus establishes life-long latency in sensory neurons, and reactivates at variable frequency manifesting as lesions around the initial point of entry - commonly the oral or genital mucosa. ${ }^{1}$ Recurrent HSV infections are unpredictable and can be painful and disabling, seriously impacting quality of life. Recurrent ocular infections can significantly affect vision and are a common cause of corneal blindness and a reason for requiring corneal transplantation. ${ }^{3}$ Asymptomatic reactivation may also occur, with significant shedding of virus, with the risk of transmission to vulnerable unprotected hosts, such as neonates or immunocompromised individuals. ${ }^{4,5}$ Perinatal exposure to HSV through an infected birth canal, or postnatal exposure following contact with individuals orally shedding HSV, can cause neonatal infections, which can be devastating with high mortality and severe neurological sequelae among survivors despite antiviral therapy. ${ }^{6}$

HSV-1 and HSV-2 are highly prevalent and endemic throughout the world. ${ }^{7,8}$ In most populations between $65 \%$ and $95 \%$ of individuals acquire HSV-1, ${ }^{7}$ and between $14 \%$ and $40 \%$ have frequent recurrent herpes labialis (RHL). ${ }^{9-11}$ Approximately one fifth of the global population acquires HSV$2,{ }^{8}$ and it is estimated that between $20 \%$ and $50 \%$ have recurrent herpes genitalis (RHG) ${ }^{12}$ resulting 
in more than 300,000 years lived with disability in 2013 according to the Global Burden of Disease Study. ${ }^{13}$ However, this estimate does not include disability due to neonatal herpes, nor the contribution of genital HSV to HIV susceptibility, which are both underestimated consequences of RHG. ${ }^{13,14}$

Antiviral agents are only moderately effective for treating HSV infection and recurrences, highlighting the need for developing novel prevention measures. Despite ongoing research, there is still no preventive or therapeutic vaccine available against HSV, ${ }^{14}$ and no intervention has been successful in stopping HSV recurrences. ${ }^{12,15}$ Oral long-term suppressive therapy with acyclovir, valacyclovir, or famciclovir is somewhat effective in reducing the frequency, severity and duration of episodes in adults with RHL or RHG, and in preventing transmission to seronegative individuals, but none fully prevent HSV recurrences and spreading. ${ }^{12,15,16}$

The Bacillus Calmette-Guérin (BCG) vaccine has a beneficial impact beyond its intended scope. ${ }^{17}$ Examples include the treatment of non-invasive bladder cancer, melanomas, lung and prostate cancer, ${ }^{18-23}$ and protection against progression of autoimmune diseases including diabetes and multiple sclerosis. ${ }^{24}$ In randomised controlled trials (RCTs) in high-mortality settings, BCG vaccination has also been associated with protection against unrelated infectious diseases, with up to $50 \%$ reduction in all-cause infant mortality. ${ }^{25}$ There is also evidence suggesting that BCG vaccination induces off-target ('non-specific') protection against a variety of viral infections, 
including HSV. ${ }^{26}$ The aim of this review was to evaluate the quality of the evidence reported by studies investigating the impact of BCG vaccination on HSV recurrences.

\section{METHODS}

Medline and EMBASE were searched in June 2020 with no language restriction. PubMed was also searched to retrieve items not indexed in Medline. The search strategy is detailed in the supplementary material. All studies investigating the effectiveness of BCG vaccination to protect against HSV were included, with no language restriction (Figure 1). For the studies that reported the proportion of participants benefitting from the intervention, data were included in a summary diagram (Figure 2). Of 193 unique articles, sixteen were deemed relevant and are summarised in Table 1 (eight animal studies) and Table 2 (eight human studies). The references of all relevant publications were reviewed and no further articles were identified.

\section{RESULTS}

\section{Animal studies}

A total of eight studies evaluated the impact of BCG administration (intradermal, intraperitoneal, or intravenous) 2 days to 4 weeks before an HSV challenge (vaginal, corneal, or intraperitoneal instillations) in mice, rabbits or guinea pigs, compared to non-vaccinated controls. In four studies, antiserum was also administered in some of the conditions, 4 hours before or 24 hours after the HSV challenge. One study tested the adoptive transfer of leucocytes from BCG-vaccinated animals 
to BCG-naïve animals. Most studies compared survival rates between groups, one study compared the clinical severity of the primary infection, and one study reported prevention of recurrence. These studies are summarised in Table 1.

\section{BCG for prevention of death}

In the largest study, the overall survival rate was 2.3-fold higher after various viral challenges in 402 mice receiving intravenous BCG (41.3\%) compared to 434 control mice (17.7\%). In particular, these rate were 5.5-fold higher following HSV-1 intraperitoneal challenge, and 1.9-fold higher following HSV-2 intraperitoneal challenge. Survival rate were increased in vaccinated mice pretreated with antiserum 4 hours prior to the viral challenge. ${ }^{27}$ In another study, intravenous BCG was associated with a 4.3-fold increased survival rate in rabbits following HSV-2 corneal scarification challenge 4 weeks after vaccination compared to non-vaccinated controls (73\% vs. 17\%). ${ }^{28} \mathrm{~A}$ third study reported a 4.1-fold higher overall survival rate associated with intraperitoneal BCG following HSV-2 intraperitoneal challenge 10 to 14 days after vaccination, with better rate in mice receiving higher dose of BCG (87-93\% survival for doses 100-1000 $\mu \mathrm{g}$ ) compared to those receiving lower doses (47\% survival for doses 50-63 $\mu \mathrm{g}) .{ }^{29}$ In another study, involving newborn mice immunised with intraperitoneal or intradermal BCG, survival rates were overall 2-fold higher following HSV-2 intraperitoneal challenge 6 days after vaccination compared with unvaccinated controls, and those receiving the highest dose of intradermal BCG had the best survival rate (3.5-fold higher). Survival rates were 6-fold higher in vaccinated mice given antiserum 24 hours after the HSV-2 challenge 
than in controls. These beneficial effect were not observed in mice not vaccinated, or those challenged earlier (2 or 4 days after BCG vaccination). ${ }^{30}$ Another study reported on the combination of intravenous BCG with anti-HSV-2 serum and showed a decreased mortality rate following intravaginal challenge with HSV-2 (20\%, vs 70\% in controls), which was lower than in groups receiving either intervention alone (BCG only: 77\% mortality; antiserum only: 50\% mortality). ${ }^{31}$ Finally, according to a conference abstract, BCG prevented death from encephalomyelitis in all rabbits challenged with intradermal HSV-2 (mortality rate 0\%, vs 100\% in controls). A similar degree of protection was observed in control rabbits who received leucocytes from BCG-immunised rabbits and anti-HSV-2 serum. ${ }^{32}$

\section{$B C G$ for prevention of recurrence or severity of primary infection}

The two last studies reported on BCG vaccination given to decrease the severity of primary infection or prevent recurrences. In the first study, intraperitoneal BCG had no influence on the severity of herpetic keratitis following HSV-1 intracorneal challenge in rabbits and guinea pigs. ${ }^{33}$ In the second, intradermal BCG was associated with a slightly lower recurrence rate of herpetic keratitis 2 months after HSV ocular challenge in rabbits, compared with controls immunised with a saline solution. ${ }^{34}$

This article is protected by copyright. All rights reserved. 


\section{Human studies}

A total of eight studies reported on the impact of BCG vaccination on HSV recurrences in humans: one $\mathrm{RCT},{ }^{35}$ six prospective trials, ${ }^{36-41}$ and one retrospective study, ${ }^{42}$ involving a total of 301 individuals, including 127 with RHL, 162 with RHG, and 12 after their first episode of herpes

genitalis (Table 2). Three of the studies were restricted to adults with $\mathrm{RHG},{ }^{35-37}$ two were restricted to RHL, ${ }^{38,39}$ and the remaining three included both RHL and RHG participants. ${ }^{40-42}$ Only one study included children. ${ }^{41}$ The BCG vaccine was given intradermally in all studies but the dose and strain varied between studies. Investigators reported on the frequency, severity and duration of recurrences after vaccination, or on the duration of recurrence-free period. The duration of the total follow-up period was rarely specified, and virological confirmation of recurrences was done in one study only.

\section{BCG for prevention of recurrent herpes genitalis}

In the RCT, 155 adults with active herpes genitalis (first episode or recurrence) were randomised to BCG vaccination or to an intradermal injection of Candida sp. antigen and were followed for approximately 10 months. The mean frequency of recurrence was unchanged after BCG vaccination, but was lower among those with RHG receiving intradermal Candida. The authors did not report on the proportion of participants with no further recurrences. ${ }^{35}$

In a prospective study of 38 adults with “severe and therapeutically recalcitrant” RHG (at least 4 episodes per year for an average duration of 2.6 years), BCG vaccination was given once a month 
for a maximum of 6 total doses. The intervention was beneficial for the majority of the participants (63\%), with 8 (21\%) remaining recurrence-free and 16 (42\%) experiencing fewer or milder episodes, while 13 participant (34\%) did not report any change in frequency or severity of recurrences, and 1 participant (3\%) reported worsened symptoms (Figure 2). ${ }^{36}$

In another prospective study, BCG was administered to 30 adults with RHG, inducing a "higher rate of clinical control and milder recurrence” when compared to 15 non-vaccinated adults with RHG. Unfortunately the authors do not provide any further details. ${ }^{37}$ However, they evaluated the participants' immune function and detected a Th1/Th2 imbalance in all 45 patients with RHG, with fewer IFN- $\gamma$-producing subsets and a low level of IL-12-producing CD8 ${ }^{+} \mathrm{T}$-cells, which normalised after BCG vaccination, reaching similar levels to healthy controls.

\section{$B C G$ for prevention of recurrent herpes labialis}

In two studies, nearly all participants benefitted from BCG vaccination: 15 (48\%) remained symptom-free, 14 (45\%) "improved clearly", and only two participants “did not respond” (6\%). Clinical improvement was associated with significant changes in an in-vitro test (HSV-Ag-induced leukocyte migration inhibition test), which remained unchanged in the two non-responders. ${ }^{38,39}$ 


\section{BCG for prevention of recurrent herpes genitalis or labialis}

The last three studies included a mix of participants with either RHG or RHL. In a trial in 12 adults with RHG and three adults with RHL, the median number of recurrence per year decreased from 10 episodes (IQR 5.8-12.0) to none (IQR 0-1.5) after receiving 1 to 2 doses of BCG, and the duration of recurrence-free period between relapses increased from a median of 1.2 months (IQR 1.0-2.1) to a median of 13 months (IQR 6.5-19.0) after vaccination. ${ }^{40}$ The majority of the participants (53\%) did not report any further recurrences after BCG vaccination, four participants (27\%) reported having fewer episodes, and 3 participants (20\%) noted no changes. Among the 7 participants with recurrences, three had remained recurrence-free until they had a recurrence during pregnancy. Among the 5 remaining non-pregnant participants, the recurrence was with another HSV type for three (therefore potentially a non-primary first episode), and in two it was with the same virus type (true recurrence). Tuberculin skin testing were done regularly and a negative reaction (after BCG vaccination or transitorily during pregnancy) was associated with recurrence, and a positive reaction after re-vaccination was associated with an absence of recurrence. ${ }^{40}$

In a trial in 109 participants with mainly RHL (98 RHL, 11 RHG), the frequency and duration of recurrences were significantly reduced after BCG vaccination. ${ }^{41}$ All participants remained recurrence-free for at least 4 to 6 months, 21 (19\%) for 3 years, and 10 (9\%) for more than 6 years. This is the only trial that included children, with participants' age ranging between 7 and 58 years (mean 30.6). ${ }^{41}$ 
In the third study, a retrospective analysis, 20 adults RHL $(n=8)$ and/or RHG (n=13) received 1 to 9 doses of BCG at 10- to 14-day intervals. They found that $35 \%$ of the patients had no recurrences, $45 \%$ had fewer and less severe recurrences, and only $20 \%$ had no change after BCG vaccination. ${ }^{42}$

\title{
DISCUSSION
}

After a growing interest in the ability of BCG vaccine to protect against HSV in the 1970s, research on this topic diminished despite promising results. In human studies, BCG vaccination was perceived as beneficial in 78\% of individuals with RHG or RHL, with 37\% being recurrence-free for an extended period, $41 \%$ experiencing less frequent or severe episodes, and only 22\% reporting no change. In the two studies restricted to RHL, BCG vaccination was associated with higher rates of protection; 48\% remaining recurrence-free and 45\% clearly improving. In another large trial, including mainly individuals with RHL, all remained episode-free for at least 4 to 6 months, and 9\% for more than 6 years.

\begin{abstract}
Albeit promising, these results are from non-randomised observational studies, using various BCG strains and doses, different durations of follow-up, and are based mainly on subjective individual report, as virological confirmation was done in one study only. The findings of the single RCT is non-contributory as the two groups had different baseline characteristics, and that the control group also received an intervention, presumably beneficial. Indeed, Candida sp. skin test antigen is also
\end{abstract}


known to induce non-specific immunomodulation, ${ }^{43,44}$ and, as suggested by the results of the trial, could therefore also prevent HSV recurrences.

In all the animal studies, BCG vaccination was associated with improved survival following viral challenge; this effect was influenced by the dose of BCG, the mode of administration and the timing between vaccination and viral challenge: higher BCG doses resulted in higher survival rate, intradermal BCG was superior to intraperitoneal BCG, and a minimum of 6 days interval were required between vaccination and the challenge to show benefit. ${ }^{30}$ The latter finding is in line with previous findings suggesting that BCG-mediated immunomodulation can be observed as early as 4 to 7 days after vaccination in mice. ${ }^{45,46} \mathrm{~A}$ similar degree of protection were observed in nonvaccinated animals transfused with leucocytes from BCG-vaccinated animals and anti-HSV-2 serum, ${ }^{32}$ highlighting the potential role of BCG-induced changes in the blood cells of vaccine recipients. This adoptive transfer experiment, reporting a dramatic beneficial effect on mortality, was reported in a conference abstract only and should therefore be interpreted with caution.

Despite wide heterogeneity in methodology, results from both the human and animal studies suggest that BCG vaccination improves the host's immune response against HSV. This is in line with previous reports of the beneficial non-specific effect of BCG vaccination, ${ }^{17-25}$ and in particular against viral pathogens. ${ }^{26}$ The underlying immunological and molecular mechanisms underlying these effects are not yet fully understood but are believed to be due to the ability of BCG to induce (i) non-specific memory in innate immune cells ('trained immunity') mediated by epigenetic and 
metabolic rewiring, and (ii) heterologous lymphocyte responses, resulting in enhanced immune responses to secondary unrelated infectious agents..$^{20,26,47,48}$

Given the high burden of disease associated with HSV infection, in particular in neonates, encephalitis, and recurrent corneal, labial and genital infections, and in absence of a definite cure, preventive interventions are needed. The results of this review suggests that BCG vaccine is a potential candidate, particularly in light of its availability, affordability and known safety profile. However, the evidence to date is predominantly from non-randomised studies. Before BCG can be recommended for prevention of RHG or RHL, further properly controlled RCTs are required to provide further information, including the influence of BCG strain, optimal dosing and need for repeat dosing, and for which patients and which type of HSV recurrences this intervention is most beneficial. 
1. Whitley RJ, Roizman B. Herpes simplex virus infections. Lancet 2001; 357: 1513-1518. DOI: 10.1016/S0140-6736(00)04638-9

2. Whitley RJ, Kimberlin DW. Herpes simplex encephalitis: children and adolescents. Semin Pediatr Infect Dis 2005; 16: 17-23. DOI: 10.1053/j.spid.2004.09.007

3. Valerio GS, Lin CC. Ocular manifestations of herpes simplex virus. Curr Opin Ophthalmol 2019; 30: 525-531. DOI: 10.1097/icu.0000000000000618

4. Ramchandani M, Kong $M$, Tronstein E, et al. Herpes simplex virus type 1 shedding in tears and nasal and oral mucosa of healthy adults. Sex Transm Dis 2016; 43: 756-760. DOI:

10.1097/olq.0000000000000522

5. Miller CS, Danaher RJ. Asymptomatic shedding of herpes simplex virus (HSV) in the oral cavity. Oral Surg Oral Med Oral Pathol Oral Radiol Endod 2008; 105: 43-50. DOI:

10.1016/j.tripleo.2007.06.011

6. Kimberlin DW. Neonatal herpes simplex infection. Clin Microbiol Rev 2004; 17: 1-13. DOI: 10.1128/cmr.17.1.1-13.2004

7. Looker KJ, Magaret AS, May MT, et al. Global and regional estimates of prevalent and incident herpes simplex virus type 1 infections in 2012. PLoS One 2015; 10: e0140765. DOI:

10.1371/journal.pone.0140765

8. Looker KJ, Magaret AS, Turner KM, Vickerman P, Gottlieb SL, Newman LM. Global estimates of prevalent and incident herpes simplex virus type 2 infections in 2012. PLoS One 2015; 10: e114989. DOI: 10.1371/journal.pone.0114989

9. Embil JA, Stephens RG, Manuel FR. Prevalence of recurrent herpes labialis and aphthous ulcers among young adults on six continents. Can Med Assoc J 1975; 113: 627-630.

10. Young TB, Rimm EB, D'Alessio DJ. Cross-sectional study of recurrent herpes labialis. Prevalence and risk factors. Am J Epidemiol 1988; 127: 612-625.

11. Spruance SL, Overall JC, Jr., Kern ER, Krueger GG, Pliam V, Miller W. The natural history of recurrent herpes simplex labialis: implications for antiviral therapy. $N$ Engl J Med 1977; 297: 69-75.

12. Le Cleach L, Trinquart L, Do G, et al. Oral antiviral therapy for prevention of genital herpes outbreaks in immunocompetent and nonpregnant patients. Cochrane Database Syst Rev 2014: Cd009036. DOI: 10.1002/14651858.CD009036.pub2

13. Global Burden of Disease Study 2013 Collaborators. Global, regional, and national incidence, prevalence, and years lived with disability for 301 acute and chronic diseases and injuries in 188 countries, 1990-2013: a systematic analysis for the Global Burden of Disease Study 2013. Lancet 2015; 386: 743-800. DOI: 10.1016/s0140-6736(15)60692-4

14. Johnston C, Gottlieb SL, Wald A. Status of vaccine research and development of vaccines for herpes simplex virus. Vaccine 2016; 34: 2948-2952. DOI: 10.1016/j.vaccine.2015.12.076

15. Chi CC, Wang SH, Delamere FM, Wojnarowska F, Peters MC, Kanjirath PP. Interventions for prevention of herpes simplex labialis (cold sores on the lips). Cochrane Database Syst Rev 2015; 8: CD010095. DOI: http://dx.doi.org/10.1002/14651858.CD010095.pub2

16. Pittet LF, Curtis N. Does oral antiviral suppressive therapy prevent recurrent herpes labialis in children? Arch Dis Child 2019; 104: 916-919. DOI: 10.1136/archdischild-2019-317249 
17. Pollard AJ, Finn A, Curtis N. Non-specific effects of vaccines: plausible and potentially important, but implications uncertain. Arch Dis Child 2017; 102: 1077-1081. DOI: 10.1136/archdischild2015-310282

18. Alexandroff AB, Jackson AM, O'Donnell MA, James K. BCG immunotherapy of bladder cancer: 20 years on. Lancet 1999; 353: 1689-1694.

19. Kamat AM, Porten S. Myths and mysteries surrounding bacillus Calmette-Guerin therapy for bladder cancer. Eur Urol 2014; 65: 267-269. DOI: S0302-2838(13)01089-0 [pii]

10.1016/j.eururo.2013.10.016

20. Kleinnijenhuis J, van Crevel R, Netea MG. Trained immunity: consequences for the heterologous effects of BCG vaccination. Trans $R$ Soc Trop Med Hyg 2015; 109: 29-35. DOI: tru168 [pii] 10.1093/trstmh/tru168

21. Pfahlberg A, Kolmel KF, Grange JM, et al. Inverse association between melanoma and previous vaccinations against tuberculosis and smallpox: results of the FEBIM study. J Invest Derm 2002; 119: 570-575. DOI: 10.1046/j.1523-1747.2002.00643.x

22. Rosenthal SR. Cancer precursors and their control by BCG. Dev Biol Stand 1986; 58: 401-416.

23. Kolmel KF, Grange JM, Krone B, et al. Prior immunisation of patients with malignant melanoma with vaccinia or BCG is associated with better survival. Europ J Cancer 2005; 41: 118-125. DOI: 10.1016/j.ejca.2004.09.023

24. Ristori G, Faustman D, Matarese G, Romano S, Salvetti M. Bridging the gap between vaccination with Bacille Calmette-Guerin (BCG) and immunological tolerance: the cases of type 1 diabetes and multiple sclerosis. Curr Opin Immunol 2018; 55: 89-96. DOI: 10.1016/j.coi.2018.09.016

25. Higgins JP, Soares-Weiser K, Lopez-Lopez JA, et al. Association of BCG, DTP, and measles containing vaccines with childhood mortality: systematic review. BMJ 2016; 355: i5170. DOI: 10.1136/bmj.i5170

26. Moorlag S, Arts RJW, van Crevel R, Netea MG. Non-specific effects of BCG vaccine on viral infections. Clin Microbiol Infect 2019; 25: 1473-1478. DOI: 10.1016/j.cmi.2019.04.020

27. Floc'h F, Werner GH. Increased resistance to virus infections of mice inoculated with BCG (Bacillus Calmette-Guérin). Ann Immunol (Paris) 1976; 127: 173-186.

28. Larson CL, Ushijima RN, Karim R, Baker MB, Baker RE. Herpesvirus hominis type 2 infections in rabbits: effect of prior immunization with attenuated Mycobacterium bovis (BCG) cells. Infect Immun 1972; 6: 465-468.

29. Glasgow LA, Fischbach J, Bryant SM, Kern ER. Immunomodulation of host resistance to experimental viral infections in mice: effects of Corynebacterium acnes, Corynebacterium parvum, and Bacille Calmette-Guérin. J Infect Dis 1977; 135: 763-770. DOI: 10.1093/infdis/135.5.763

30. Starr SE, Visintine AM, Tomeh MO, Nahmias AJ. Effects of immunostimulants on resistance of newborn mice to herpes simplex type 2 infection. Proc Soc Exp Biol Med 1976; 152: 57-60. DOI: 10.3181/00379727-152-39327

31. Baker MB, Larson CL, Ushijima RN, Anderson FD. Resistance of female mice to vaginal infection induced by herpesvirus hominis type 2: effects of immunization with Mycobacterium bovis, intravenous injection of specific herpesvirus hominis type 2 antiserum, and a combination of these procedures. Infect Immun 1974; 10: 1230-1234.

32. Lehel F, Harsany M, Toth I. Influence of BCG immunization on the course of experimental herpes simplex virus infection in rabbits. Acta Microbiol Acad Sci Hung 1978; 25: 135.

33. Smolin G, Okumoto M, Meyer R, Belfort R, Jr. Effect of immunization with attenuated Mycobacterium bovis (BCG) on experimental herpetic keratitis. Can J Ophthalmol 1975; 10: 385-390. 
34. Kaufman HE, Mudd S, Varnell ED, Engelstein J. The effect of nonspecific immune stimulation on the recurrence rate of herpetic keratitis in rabbits. Invest Ophthalmol 1975; 14: 469-471.

35. Douglas JM, Vontver LA, Stamm WE, et al. Ineffectiveness and toxicity of BCG vaccine for the prevention of recurrent genital herpes. Antimicrob Agents Chemother 1985; 27: 203-206. DOI:

10.1128/aac.27.2.203

36. Bierman SM. BCG immunoprophylaxis of recurrent herpes progenitalis. Arch Dermatol 1976;

112: $1410-1415$.

37. Deng YH, Chen XP, Xu CR, Chen YL, Wan M, Yang DL. Enhancement of BCG-PSN on the cytokines in $\mathrm{CD}^{+} \mathrm{T}$ lymphocytes in the peripheral blood of patients with recurrent genital herpes.

Chinese J Microbiol Immunol 2004; 24: 901-904.

38. Jarisch R, Sandor I, Cerni C. The leukocyte migration inhibition test (LMIT) in recurrent herpes simplex labialis. Comparison of the results of treatment with BCG and Levamisole (author's transl). Arch Dermatol Res 1979; 265: 15-22. DOI: 10.1007/bf00412697

39. Jarisch R, Sandor I. Therapy of recurrent herpes simplex and its surveillance by MIF determination: with levamisole, BCG, urushiol and herpes antigen vaccine (author's transl). Arch Dermatol Res 1977; 258: 151-159.

40. Anderson FD, Ushijima RN, Larson CL. Recurrent herpes genitalis. Treatment with Mycobacterium bovis (BCG). Obstet Gynecol 1974; 43: 797-805.

41. Hippmann G, Wekkeli M, Rosenkranz AR, Jarisch R, Gotz M. Nonspecific immune stimulation with BCG in herpes simplex recidivans. Follow-up 5 to 10 years after BCG vaccination. Wien Klin Wochenschr 1992; 104: 200-204.

42. Fanta D, Dostal V, Reiss-Gutfreund R. BCG therapy of recurrent herpes simplex type 1 and 2 (HSV-1 and 2). Z Hautkr 1977; 52: 1099-1104.

43. Nakagawa M, Coleman HN, Wang X, Daniels J, Sikes J, Nagarajan UM. IL-12 secretion by Langerhans cells stimulated with Candida skin test reagent is mediated by dectin- 1 in some healthy individuals. Cytokine 2014; 65: 202-209. DOI: 10.1016/j.cyto.2013.11.002

44. Wang X, Coleman HN, Nagarajan U, Spencer HJ, Nakagawa M. Candida skin test reagent as a novel adjuvant for a human papillomavirus peptide-based therapeutic vaccine. Vaccine 2013; 31: 58065813. DOI: 10.1016/j.vaccine.2013.10.014

45. Freyne B, Donath S, Germano S, et al. Neonatal BCG vaccination influences cytokine responses to Toll-like receptor ligands and heterologous antigens. J Infect Dis 2018; 217: 1798-1808. DOI: 10.1093/infdis/jiy069

46. Blok BA, de Bree LCJ, Diavatopoulos DA, et al. Interacting, nonspecific, immunological effects of Bacille Calmette-Guérin and tetanus-diphtheria-pertussis inactivated polio vaccinations: An explorative, randomized trial. Clin Infect Dis 2020; 70: 455-463. DOI: 10.1093/cid/ciz246

47. Goodridge HS, Ahmed SS, Curtis N, et al. Harnessing the beneficial heterologous effects of vaccination. Nat Rev Immunol 2016; 16: 392-400. DOI: nri.2016.43 [pii] 10.1038/nri.2016.43

48. Netea MG, Dominguez-Andres J, Barreiro LB, et al. Defining trained immunity and its role in health and disease. Nat Rev Immunol 2020; 20: 375-388. DOI: 10.1038/s41577-020-0285-6 


\begin{tabular}{|c|c|c|c|}
\hline Citation & Study group & Outcome & Key Result \\
\hline \multicolumn{4}{|c|}{ Prevention of death following viral challenge } \\
\hline $\begin{array}{l}\text { Floc'h et al. } \\
1976^{27}\end{array}$ & $\begin{array}{l}\text { P: } 4-6 \text { wo CD-1 or OF-1 mice } \\
\left.\text { I: BCG i.v. (Pasteur, } 1 \mathrm{mg} \cong 10^{6} \mathrm{~B}\right)+/- \text { antiserum } 4 \mathrm{~h} \text { prior chal. } \\
\text { Chal.: } 15-31 \text { later, HSV-1 or HSV-2 i.p., or other virus, various routes }\end{array}$ & $\begin{array}{l}\text { Death following } \\
\text { challenge } \\
\text { (BCG vs. no BCG) }\end{array}$ & $\begin{array}{l}\text { Overall: } 58.7 \%(236 / 402) \text { vs } 82.3 \%(357 / 434), p<.001 \\
\text {-HSV-1 i.p. challenge: } 40 \%(18 / 45) \text { vs } 89 \%(40 / 45), p<.001 \\
\text {-HSV-2 i.p. challenge: } 55 \%(39 / 71) \text { vs } 76 \%(54 / 71), p=.008\end{array}$ \\
\hline $\begin{array}{l}\text { Larson et al. } \\
1972^{28}\end{array}$ & $\begin{array}{l}\text { P: Angora, New Zealand, and Dutch-belted rabbits } \\
\text { I: BCG i.v. }\left(4^{\star} 10^{7} \text { B) }\right. \\
\text { Chal.: } 4 \text { w later, HSV-2 vag. or i.c. }\end{array}$ & $\begin{array}{l}\text { Death following } \\
\text { challenge } \\
\text { (BCG vs. no BCG) }\end{array}$ & $\begin{array}{l}\text { i.c. scarification: } \mathbf{2 7} \%(\mathbf{8} / 30) \text { vs } \mathbf{8 3} \%(\mathbf{2 5 / 3 0}), \mathbf{p}<.001 \\
\text { I.c. injection: } 67 \%(4 / 6) \text { vs } 100 \%(6 / 6), p=0.5 \\
\text { Vag. instillation: } 62 \%(8 / 13) \text { vs } 82 \%(9 / 11), p=0.3\end{array}$ \\
\hline $\begin{array}{l}\text { Glasgow et al. } \\
1977^{29}\end{array}$ & $\begin{array}{l}\text { P: Female white Swiss Webster mice } \\
\text { I: BCG i.p. (Paris strain, } 200 \mu \mathrm{g} \text { ) } \\
\text { Chal.: } 10-14 \mathrm{~d} \text { later, HSV-2 i.p. }\end{array}$ & $\begin{array}{l}\text { Death following } \\
\text { challenge } \\
\text { (BCG vs. no BCG) }\end{array}$ & $\begin{array}{l}\mathbf{4 7 \%}(\mathbf{7 / 1 5}) \text { vs } \mathbf{8 7 \%}(\mathbf{2 6 / 3 0 )}, \mathbf{p}<.01 \\
(7-13 \% \text { for BCG doses } 100-1000 \mu \mathrm{g}, 53 \% \text { for BCG dose } 50-63 \mu \mathrm{g})\end{array}$ \\
\hline $\begin{array}{l}\text { Starr et al. } \\
1976^{30}\end{array}$ & $\begin{array}{l}\text { P: } 1-2 \text { do Swiss mice } \\
\text { I: BCG i.p. or i.d., full or } 1 / 5 \text { dose (Tice strain, } 8^{\star} 10^{8} \mathrm{~B} / \mathrm{ml} \text { ) }+/ \text { - antiserum } \\
\text { i.p. } 24 \mathrm{~h} \text { after chal. } \\
\text { Chal.: } 2 \mathrm{~d}, 4 \mathrm{~d} \text {, or } 6 \mathrm{~d} \text { later, HSV-2 i.p. }\end{array}$ & $\begin{array}{l}\text { Death after viral } \\
\text { challenge } \\
\text { (BCG vs. no BCG) }\end{array}$ & $\begin{array}{l}\text { Challenge D2, BCG i.p. (full dose): } 90 \%(28 / 31) \text { vs } 100 \%(9 / 9), p=1 \\
\text { Challenge D4, BCG i.p. (full dose): } 92 \%(22 / 24) \text { vs } 100 \%(9 / 9), p=1 \\
\text { Challenge D6, BCG i.p. (overall): } \mathbf{4 6 \%}(\mathbf{1 2 / 2 6 )} \text { vs } \mathbf{1 0 0 \%}(\mathbf{9 / 9}), \mathrm{p}=.005 \\
\text {-Full BCG: } 50 \%(3 / 6) \text { vs } 100 \%(9 / 9), p=.04 \\
-1 / 5 \text { BCG: } 45 \%(9 / 20) \text { vs } 100 \%(9 / 9), p=.005 \\
\text { Challenge D6, BCG i.d. (overall): } \mathbf{5 8 \%}(\mathbf{7 / 1 2}) \text { vs } \mathbf{1 0 0 \% ( 9 / 9 ) , ~} \mathrm{p}=. \mathbf{0 4 5} \\
\text {-Full BCG: } 29 \%(2 / 7) \text { vs } 100 \%(9 / 9), p=.005 \\
-1 / 5 \text { BCG: } 100 \%(5 / 5) \text { vs } 100 \%(9 / 9)\end{array}$ \\
\hline $\begin{array}{l}\text { Baker et al. } \\
1974{ }^{31}\end{array}$ & $\begin{array}{l}\text { P: Female white Swiss mice } \\
\text { I: BCG i.v. }\left(1^{\star} 10^{7} B\right)+/- \text { antiserum } 4 \text { h prior chal. } \\
\text { Chal.: } 7-10 d \text { later, HSV-2 vag. }\end{array}$ & $\begin{array}{l}\text { Death after viral } \\
\text { challenge }\end{array}$ & $\begin{array}{l}\text { BCG + antiserum: } \sim 20 \% \\
\text { BCG alone: } \sim 77 \% \\
\text { Antiserum alone: } \sim 50 \% \\
\text { Control: } \sim 70 \%\end{array}$ \\
\hline $\begin{array}{l}\text { Lehel et al. } \\
1978^{32}\end{array}$ & $\begin{array}{l}\text { P: rabbits } \\
\text { I: BCG or adoptive transfer of leucocytes from BCG-immunised rabbit } \\
\text { and antiserum (no detail provided, conference abstract) } \\
\text { Chal.: HSV-2 i.d. }\end{array}$ & $\begin{array}{l}\text { Death after viral } \\
\text { challenge }\end{array}$ & $\begin{array}{l}\text { BCG: } 0 \% \\
\text { Control: } 100 \% \\
\text { Control with leucocyte from BCG-immunised rabbit and antiserum: } 0 \%\end{array}$ \\
\hline \multicolumn{4}{|c|}{ Prevention of severity or recurrence } \\
\hline $\begin{array}{l}\text { Smolin et al. } \\
1975^{33}\end{array}$ & $\begin{array}{l}\text { P: guinea pigs and rabbits } \\
\text { I: BCG i.p. (Pasteur, } 0.5 \mathrm{ml} \cong 10^{3.5} \text { B), } 2 \text { doses } \\
\text { Chal.: } 5 \text { d after } 2^{\text {nd }} \text { BCG dose, HSV-1 i.c. } 0.01 \mathrm{ml}\left(\text { LD50 } 10^{5} / 0.03 \mathrm{ml}\right)\end{array}$ & $\begin{array}{l}\text { Herpetic keratitis } \\
\text { severity } \\
\text { (BCG vs no BCG, } \\
\text { mean score) }\end{array}$ & $\begin{array}{l}\text { Guinea pigs: } \\
\text { D1: } 2.7 \text { (range } 2-4 \text { ) vs } 3.3 \text { (range } 2-4 \text { ) } \\
\text { D2: } 0.9 \text { (range } 0-2) \text { vs } 1.5 \text { (range } 0-4) \\
\text { D3: } 0.9 \text { (range } 0-2 \text { ) vs } 0.9 \text { (range } 0-4 \text { ) } \\
\text { Rabbits: } \\
\text { D2: } 1.3 \text { (range } 1-2 \text { ) vs } 1.4 \text { (range } 1-2 \text { ) } \\
\text { D3: } 1.9 \text { (range } 1-3 \text { ) vs } 2.1 \text { (range } 1-3 \text { ). }\end{array}$ \\
\hline
\end{tabular}

This article is protected by copyright. All rights reserved. 
Kaufman et al. P: New Zealand rabbits

$1975^{34}$

I: $B C G$

and behind each ears)

Chal.: 15d later, HSV i.c. (McKrae)
Herpetic lesion

(BCG vs no BCG

mean number of

lesion/cornea/

(SD 5.07) vs 4.03 (SD 4.75)

59-65: 2.85 (SD 4.74) vs 7.00 (SD 8.90), $p<.05$

D66-72: 6.69 (SD 9.05) vs 7.54 (SD 11.56)

D73-79: 5.54 (SD 7.57) vs 4.25 (SD 5.63)

D80-84: 3.04 (SD 4.23) vs 4.77 (SD 8.11)

BCG: Bacille Calmette-Guérin; chal.: challenge; d: day; i.c.: corneal; i.d.: intradermal; i.v.: intravenous; mo: months-old; vag.: intravaginal; wo: weeks-old.

This article is protected by copyright. All rights reserved. 
Table 2: BCG vaccination for reducing the recurrence and severity of herpes labialis and genitalis

\begin{tabular}{|c|c|c|c|c|}
\hline $\begin{array}{l}\text { Citation } \\
\text { Country }\end{array}$ & Study group & Study type & Outcome & Key results \\
\hline \multicolumn{5}{|c|}{ Prevention of recurrent herpes genitalis } \\
\hline \multirow[t]{2}{*}{$\begin{array}{l}\text { Douglas et al. } \\
1985^{35} \\
\text { USA }\end{array}$} & $\begin{array}{l}155 \text { adults (mean age } 27.2 \mathrm{y}, \mathrm{SD} 6.8) \text { with RHG }(\mathrm{n}=134) \text { or } \mathrm{FHG}(\mathrm{n}=21) \\
\mathrm{Gp1} \text { : BCG Glaxo strain }\left(0.1 \mathrm{ml} \cong 2 * 10^{5} \mathrm{~B}\right) \\
\mathrm{n}=83(71 \mathrm{RHL}, 12 \mathrm{FHG})\end{array}$ & \multirow[t]{2}{*}{$\begin{array}{l}\text { Double-blind } \\
\text { RCT }\end{array}$} & \multirow[t]{2}{*}{$\begin{array}{l}\text { Frequency of } \\
\text { recurrence }\end{array}$} & $\begin{array}{l}\text { Before BCG: } 0.608 / \mathrm{m}, \text { SD } 0.412 \\
\text { After BCG: } 0.528 / \mathrm{m} \\
\text {-among RHG: } 0.532 / \mathrm{m}\end{array}$ \\
\hline & $\begin{array}{l}\text { Gp2: Candida sp. skin test antigen 0.1ml i.d., } \\
\mathrm{n}=72(63 \mathrm{RHL}, 9 \mathrm{FHG})\end{array}$ & & & $\begin{array}{l}\text { Before Candida: } 0.747 / \mathrm{m}, \mathrm{SD} 0.502 \\
\text { After Candida: } 0.392 / \mathrm{m}(p=.08 \text {, vs BCG) } \\
\text {-among RHG: } 0.357 / \mathrm{m}(p<.002 \text {, vs BCG) }\end{array}$ \\
\hline \multirow{3}{*}{$\begin{array}{l}\text { Bierman } \\
1976^{36} \\
\text { USA }\end{array}$} & 38 adults (mean age 33y, range 20-57) with RHG & \multirow{3}{*}{$\begin{array}{l}\text { Interventional } \\
\text { study }\end{array}$} & \multirow{2}{*}{$\begin{array}{l}\text { Frequency } \\
\text { and severity } \\
\text { of recurrence }\end{array}$} & $8(21 \%)$ no recurrences \\
\hline & \multirow[t]{2}{*}{ BCG Glaxo strain $1 \mathrm{ml} 1 x / \mathrm{m}$, max 6 doses } & & & $\begin{array}{l}16(42 \%) \text { fewer and milder episodes } \\
13(34 \%) \text { no change in frequency or severity } \\
1(3 \%) \text { worsened }\end{array}$ \\
\hline & & & Side effect & 9 (24\%), abscess at site of inoculation \\
\hline \multirow{2}{*}{$\begin{array}{l}\text { Deng et al. } \\
2004^{37} \\
\text { China }\end{array}$} & 45 adults with RHG & \multirow{2}{*}{$\begin{array}{l}\text { Interventional } \\
\text { study }\end{array}$} & \multirow{2}{*}{$\begin{array}{l}\text { Frequency } \\
\text { and severity } \\
\text { of recurrence }\end{array}$} & \multirow{2}{*}{$\begin{array}{l}\text { "Higher rate of clinical control and milder recurrence in } \\
\text { the BCG group" compared to } 15 \text { non-vaccinated adults }\end{array}$} \\
\hline & BCG (no detail provided) & & & \\
\hline \multicolumn{5}{|c|}{ Prevention of recurrent herpes labialis } \\
\hline \multirow{2}{*}{$\begin{array}{l}\text { Jarisch et al. } \\
1977^{39} \\
\text { Austria }\end{array}$} & 8 adults with $\mathrm{RHL}$ & \multirow{2}{*}{$\begin{array}{l}\text { Interventional } \\
\text { study }\end{array}$} & \multirow{2}{*}{$\begin{array}{l}\text { Frequency } \\
\text { and severity } \\
\text { of recurrence }\end{array}$} & \multirow{2}{*}{$\begin{array}{l}5(63 \%) \text { had no recurrence } \\
3(38 \%) \text { had shorter episodes }\end{array}$} \\
\hline & BCG Berna $\left(0.1 \mathrm{ml} \cong 8-26^{\star} 10^{5} \mathrm{~B}\right)$ & & & \\
\hline \multirow{2}{*}{$\begin{array}{l}\text { Jarisch et al. } \\
1979^{38} \\
\text { Austria }\end{array}$} & 23 adults (mean age $33 y$, range $18-52$ ) with $\mathrm{RHL}$ & \multirow{2}{*}{$\begin{array}{l}\text { Interventional } \\
\text { study }\end{array}$} & \multirow{2}{*}{$\begin{array}{l}\text { Frequency } \\
\text { and severity } \\
\text { of recurrence }\end{array}$} & $10(44 \%)$ remained symptom-free \\
\hline & BCG Berna $\left(0.1 \mathrm{ml} \cong 8-26 * 10^{5} \mathrm{~B}\right)$ & & & $\begin{array}{l}11(48 \%) \text { "improved clearly" } \\
2 \text { (9\%) "did not respond" }\end{array}$ \\
\hline \multicolumn{5}{|c|}{ Prevention of recurrent herpes genitalis or labialis } \\
\hline \multirow{4}{*}{$\begin{array}{l}\text { Anderson et al. } \\
197440 \\
\text { USA }\end{array}$} & 15 adults with RHG (12) or RHL (3) & \multirow{4}{*}{$\begin{array}{l}\text { Interventional } \\
\text { study }\end{array}$} & \multirow{3}{*}{$\begin{array}{l}\text { Frequency } \\
\text { and severity } \\
\text { of recurrence }\end{array}$} & $8(53 \%)$ had no recurrences \\
\hline & \multirow{3}{*}{$\begin{array}{l}\text { BCG Glaxo }\left(0.1 \mathrm{ml} \cong 5^{\star} 10^{5} \mathrm{~B}\right) \\
\text { Some received a second dose }\end{array}$} & & & $\begin{array}{l}4(27 \%) \text { had fewer episodes } \\
3(20 \%) \text { noted no change }\end{array}$ \\
\hline & & & & $\begin{array}{l}\text { Before BCG: median 10/y, IQR 5.8-12.0 } \\
\text { After BCG: median 0/y, IQR 0-1.5 }\end{array}$ \\
\hline & & & $\begin{array}{l}\text { Time between } \\
\text { recurrences }\end{array}$ & $\begin{array}{l}\text { Before BCG: median } 1.2 \text { m, IQR 1-2.1 } \\
\text { After BCG: median } 13 \text { m, IQR 6.5-19 }\end{array}$ \\
\hline
\end{tabular}

This article is protected by copyright. All rights reserved. 


\begin{tabular}{|c|c|c|c|c|}
\hline $\begin{array}{l}\text { Hippmann et al. } \\
199241 \\
\text { Austria }\end{array}$ & $\begin{array}{l}109 \text { individuals (mean age } 30.6 y \text {, range } 7-58) \text { with } \mathrm{RHL}(98) \text { or RHG (11) } \\
\text { BCG Berna }\left(0.1 \mathrm{ml} \cong 8-26^{\star} 10^{5} \mathrm{~B}\right)\end{array}$ & $\begin{array}{l}\text { Interventional } \\
\text { study }\end{array}$ & $\begin{array}{l}\text { Duration of } \\
\text { recurrence- } \\
\text { free period }\end{array}$ & $\begin{array}{l}109(100 \%) \text { for } \geq 4-6 m \\
21(19 \%) \text { for } \geq 3 y \\
10(9 \%) \text { for } \geq 6 y\end{array}$ \\
\hline $\begin{array}{l}\text { Fanta et al. } \\
1977^{42} \\
\text { Austria }\end{array}$ & $\begin{array}{l}20 \text { adults (mean age } 42 \mathrm{y} \text {, range } 26-65) \text { with } \mathrm{RHL}(\mathrm{n}=8) \text { and/or RHG }(\mathrm{n}=13) \\
\text { BCG Pasteur } 0.05 \mathrm{ml} \text {, then } 0.1 \mathrm{ml} \text { every } 10-14 \mathrm{~d} \\
(1 \text { to } 9 \text { total doses) }\end{array}$ & Retrospective & $\begin{array}{l}\text { Frequency } \\
\text { and severity } \\
\text { of recurrence }\end{array}$ & $\begin{array}{l}7(35 \%) \text { had no recurrences ("only prodromal symptoms") } \\
4(20 \%) \text { rare episodes, less severe, shorter duration } \\
5(25 \%) \text { fewer episodes, less severe } \\
4(20 \%) \text { noted no change }\end{array}$ \\
\hline
\end{tabular}
trial; RHG: recurrent herpes genitalis; RHL: recurrent herpes labialis; SD: standard deviation; USA: United States of America; y: year. 


\section{FIGURES LEGEND}

Figure 1: PRISMA flow diagram of systematic review

Figure 2: Clinical response to BCG vaccination in adults with recurrent HSV infections BCG: Bacille Calmette-Guérin; HSV: herpes simplex virus; RHG: recurrent herpes genitalis; RHL: recurrent herpes labialis.

In the study by Fanta et al, one patient reported both RHG and RHL. ${ }^{42}$

This article is protected by copyright. All rights reserved. 


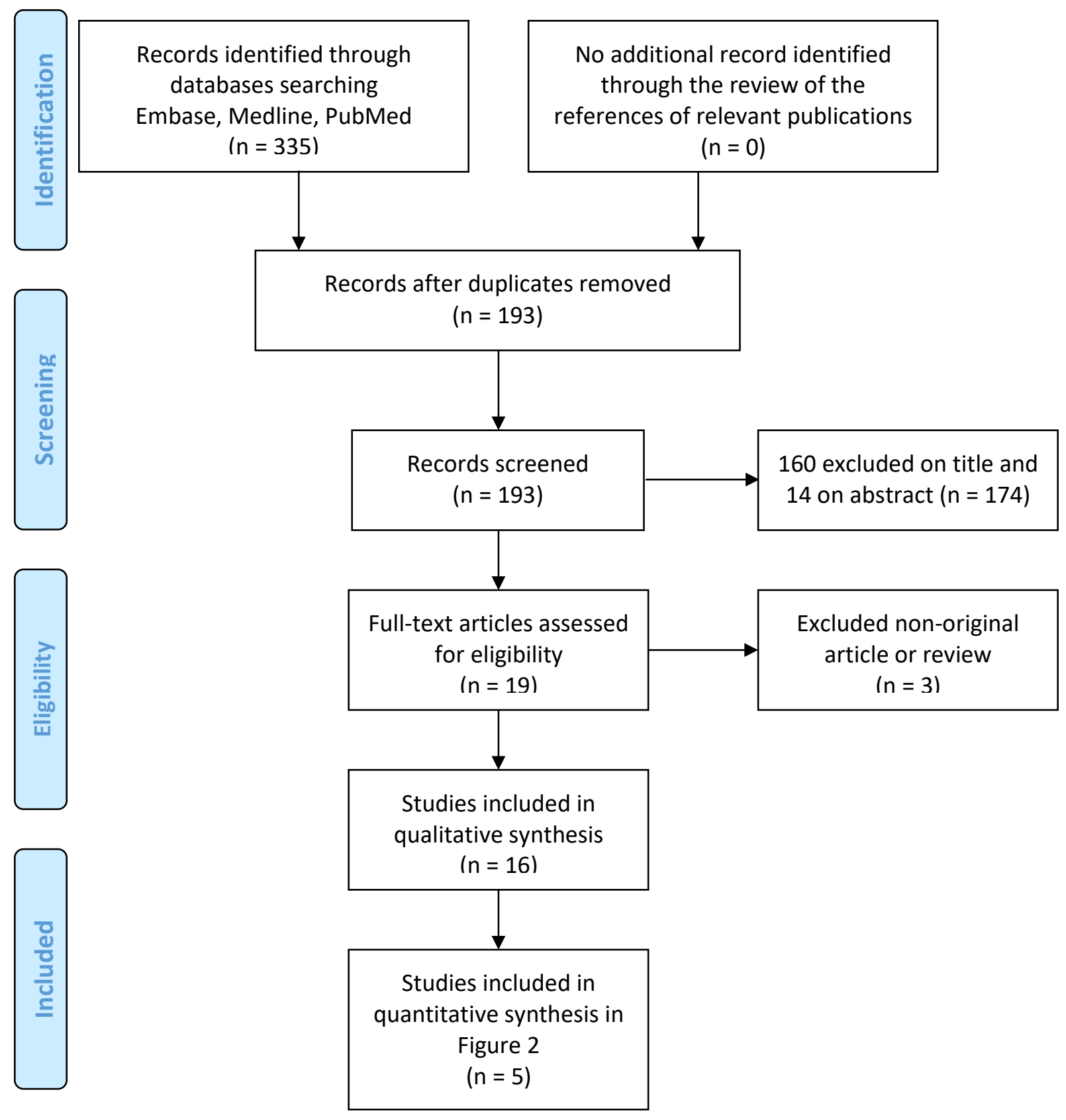

This article is protected by copyright. All rights reserved. 

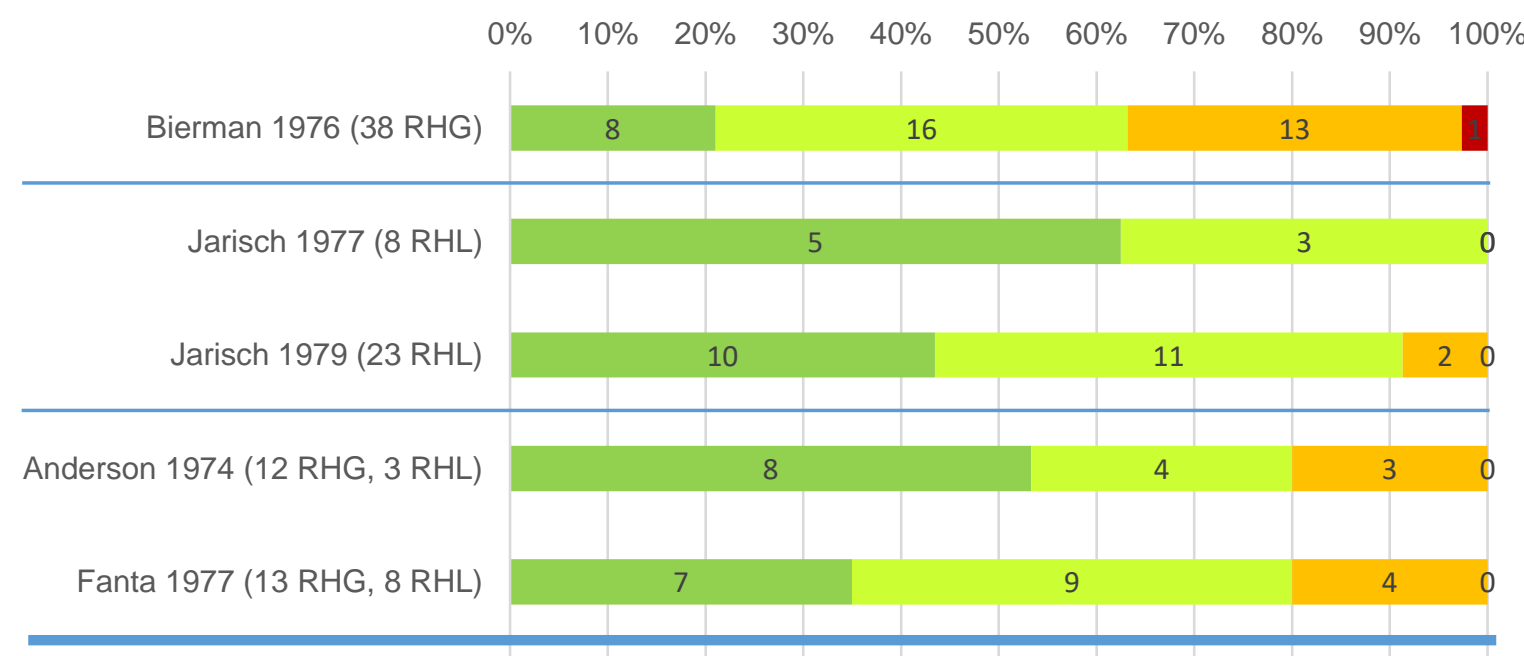

Overall (63 RHG, 42 RHL)

38

43

22

No recurrence $\quad$ Fewer and/or milder recurrences $\quad$ No change $\quad$ Worsen 


\section{University Library}

\section{- M M N E R VA A gateway to Melbourne's research publications}

Minerva Access is the Institutional Repository of The University of Melbourne

Author/s:

Pittet, LF;Curtis, N

Title:

Does bacillusCalmette-Guerinvaccine prevent herpes simplex virus recurrences? A systematic review

Date:

2020-09-24

\section{Citation:}

Pittet, L. F. \& Curtis, N. (2020). Does bacillusCalmette-Guerinvaccine prevent herpes simplex virus recurrences? A systematic review. REVIEWS IN MEDICAL VIROLOGY, 31 (1), https://doi.org/10.1002/rmv.2151.

Persistent Link:

http://hdl.handle.net/11343/276347 